\title{
Soil Properties Conducive to the Formation of Tuber aestivum Vitt. Fruiting Bodies
}

\author{
Dorota Hilszczańska $^{1 *}$, Hanna Szmidla², Katarzyna Sikora², \\ Aleksandra Rosa-Gruszecka ${ }^{1}$
}

${ }^{1}$ Forest Research Institute, Department of Forest Ecology, Raszyn, Poland

${ }^{2}$ Forest Research Institute, Department of Forest Protection, Raszyn, Poland

\author{
Received: 19 February 2018 \\ Accepted: 27 March 2018
}

\begin{abstract}
Summer truffle (Tuber aestivum), also known as Burgundy truffle, is getting interest in Poland in terms of cultivation as a promising incentive for rural areas. Yet the occurrence of the fungus in wider scale in our country has been confirmed in the last decade. Ecological factors that determine the occurrence of T. aestivum are rather well known in the Mediterranean region, whereas such knowledge is limited in northern Europe. The aim of this work was to find the correlations between essential nutrients in surface horizons of soils typical of truffle occurrence. The study area is situated in the Nida Basin in southern Poland. Principal component analysis (PCA) showed that active carbonate content is the variable that accounts for the greatest percentage of occupancy in the T. aestivum habitat. In this paper we propose that active carbonate is a major factor in the fruiting of summer truffle. The obtained results could have applications in natural harvesting and truffle culture.
\end{abstract}

Keywords: summer truffle, habitats, soil composition, stands

\section{Introduction}

Burgundy truffle Tuber aestivum Vittad., one of the species among black truffles, is a prized fungus due to its taste and aroma. This hypogeous species is found throughout Europe [1,2] and belongs to the Pezizales, a large group of ectomycorrhizal fungi that form mutualistic symbioses with the roots of angiosperms and gymnosperms [3]. T. aestivum forms ectomycorrhizal symbioses with many different species, including Corylus avellana, Quercus robur, Fagus sylvatica, Tilia cordata, and Pinus nigra. This truffle species prefers calcareous soils with $\mathrm{pH}$ levels near or above 7-8, although it occurs in beech woods on limedeficient soils in the United Kingdom [4].

Both historical [5] and contemporary data show that $T$. aestivum and other truffle species have been reported from Poland [6-8] and the situation is similar for neighbouring countries the Czech Republic [9] and Germany [10]. So far, known localities of the fungus have been confirmed in southern Poland on soils that represent rendzinas type of soil formed on bedrock that belongs to marlstone, marly limestone, and gypsum [7]. It seems that the best conditions for fructification of T. aestivum are in mixed broadleaved forests which are no older than 30 years [6].

*e-mail: d.hilszczanska@ibles.waw.pl 
The importance of soil chemical and physical characteristics for truffle (e.g. T. aestivum) ectomycorrhiza development and fruiting bodies (ascocarps) formation in plantation and natural stands is well documented [11]. However, Granetti and co-authors [3] claim that there is a lack of knowledge as to how the physical-chemical properties of soil shape natural truffle development. In addition, the microbiology, site ecology, and host specificity of $T$. aestivum is poorly understood [10, 12]. Gryndler and co-authors [13] suggest that non-host (not known to form ectomycorrhiza with a given fungal symbiont) plants may also be important for truffle production since the association of $T$. aestivum mycelium with the non-host plants plays a functional role. The presence of the mycelium can induce substantial changes in the vegetation layer of $T$. aestivum inhabited stands and result in important consequences for carbon and nutrient cycling in the ecosystem. Furthermore, the suggestion that truffle-related soil microorganisms may be less important for the stimulation of truffle hyphal growth than the complete soil has been made [9].

Here we emphasize soil properties of the surface horizons in four stands with fruiting bodies of T. aestivum, to find out which soil factors shape the fructification of truffles the most. To our best knowledge it is the first work done on the subject in Poland. The results are expected to be very useful for truffle plantation owners and managers, whose number is increasing every year in Central and Eastern European countries.

\section{Material and Methods}

\section{Study Area}

The study area is located in the Nida Basin in southern Poland. Four stands representing mixed deciduous forest were chosen. The stands are indicated with symbols: PO, WR, GR, and SA, and their altitudinal gradients are 247, 290, 264, and $319 \mathrm{~m}$ a.s.1., respectively. At each stand three plots $\left(100 \mathrm{~m}^{2}\right)$ were established to study the occurrence of truffles, physicchemical properties of soil, and type of vegetation. All those forests are situated close together in a basin sharing similar topographic and microclimatic conditions; geographic coordinates are: $50^{\circ} 25^{\prime}-50^{\circ} 28^{\prime} \mathrm{N}$ and $20^{\circ} 19^{\prime}-20^{\circ} 48^{\prime} \mathrm{E}$. Average annual precipitation is $600 \mathrm{~mm}$, with a low yearly average temperature of $8.0^{\circ} \mathrm{C}$ [14]. Its lithology comprises Jurassic and Cretaceous limestone and marlstone, and soils are rendzic leptosols. The forests represent the geo-botanical classification type of Tillio-Carpinetum typicum [15].

\section{Soil Snalysis}

In total, five samples of soil were taken at each plot. The analysis was done for one mixed sample for each plot, so twelve samples of soil were analysed. The soil was sampled by removing the litter and vegetation layers and then collecting approximately $0.5 \mathrm{~kg}$ of soil down to a depth of 20-30 cm, depending on the rockiness of the soil. The soil analyses were performed in the laboratory of the Polish Centre for Accreditation (No. AB740). The soil $\mathrm{pH}$ in water and essential nutrient contents (Table 1) were measured according to ISO 10390 (1997) and PB-14ed.2 of 1 January 2010 (using inductively coupled argon-plasma spectrometry following mineralisation in chloric (VII) acid), a percentage of $\mathrm{N}$ and total organic carbon (TOC) - ISO13878 (2002) and PN-ISO 10694 (2002), content of carbon calcium (percent) -Scheibler's method (ISO 10693, 1994), and exchangeable cations (Ca, Mg, K, Na) - ISO 11260 (2011), respectively. The soil texture was measured based on three particle-sized fractions: $<2 \mu \mathrm{m}$ (clay), 2-63 $\mu \mathrm{m}$ (silt), and 63-2000 $\mu \mathrm{m}$ (sand) (ISO 11277, 2005)

\section{Truffle Harvest and Taxonomic Studies}

The truffle localities at the stands were found using trained truffle dogs in collaboration with researchers from the Agricultural University in Nitra (Slovakia). Inventories were made in 2012-2014, and 532 fruiting bodies were found for all sites. Species of truffles were identified on the basis of microscopic features and compared to the criteria by Granetti et al. [3] and Molinier et al. [16]. Samples of fruiting bodies were also taken for molecular identification. The sequences are deposited in Genbank NCBI (KJ524517-KJ524528).

\section{Statistical Analysis}

Data were analysed using Statistica v. 10 (Dell, 2016). Normality was checked using the Shapiro-Wilk test. The homogeneity of variance was also checked by using the Levene test and the Brown-Forsythe test. Principal component analysis (PCA) was done with 11 soil variables of 12 soil samples (Table 1) to show the variation patterns of those elements potentially associated with the presence of Tuber aestivum in four natural stands. Data regarding the number of T. asetivum fruiting bodies and the value of $\mathrm{CaCO}_{3}$ were log-transformed to meet the requirements of parametric correlation (Pearson test) with the $\mathrm{p}$-value $\leq 0.05$.

\section{Results}

Soil physicochemical characteristics are a key factor for truffles' fruiting bodies development. Even when a tree or shrubs are well mycorrhizaed and the climate is favourable, fruiting cannot take place if certain soil parameters are inappropriate.

Table 1 shows investigated soil parameters. The soils have silty clay loam, loam, and clay loam texture. Most of the investigated soils have $\mathrm{pH}$ above 7.0 and a low 
Table 1. Texture and chemical composition of the analysed soils.

\begin{tabular}{|c|c|c|c|c|c|c|c|c|c|c|c|}
\hline No. & Sand & Silt & Clay & $\mathrm{pH}$ & $\mathrm{CaCO}_{3}$ & $\mathrm{TOC}$ & $\mathrm{N}^{+}$ & $\mathrm{Ca}^{2+}$ & $\mathrm{Mg}^{2+}$ & $\mathrm{K}^{+}$ & $\mathrm{Na}^{+}$ \\
\hline PO & 9.2 & 40.5 & 50.3 & 7.5 & 31.2 & 5.41 & 0.45 & 44.8 & 1.51 & 1.27 & 0.041 \\
\hline PO & 8.4 & 47.12 & 44.48 & 7.4 & 2.53 & 4.64 & 0.39 & 46.6 & 1.3 & 0.68 & 0.064 \\
\hline PO & 6.69 & 37.91 & 55.4 & 6.3 & 0.26 & 2.7 & 0.218 & 27.5 & 1.17 & 0.62 & 0.064 \\
\hline WR & 23.71 & 52.0 & 24.29 & 7.4 & 8.62 & 4.97 & 0.46 & 46.1 & 1.22 & 0.72 & 0.04 \\
\hline WR & 16.88 & 53.05 & 30.07 & 7.4 & 17.61 & 4.99 & 0.47 & 43.5 & 1.35 & 0.64 & 0.038 \\
\hline WR & 25.08 & 47.7 & 27.22 & 7.6 & 36.56 & 3.38 & 0.302 & 30.0 & 0.57 & 0.58 & 0.03 \\
\hline SA & 13.22 & 41.47 & 45.31 & 7.3 & 1.26 & 2.68 & 0.22 & 31.8 & 1.08 & 0.53 & 0.072 \\
\hline SA & 23.6 & 42.4 & 34.0 & 7.4 & 6.74 & 3.79 & 0.325 & 38.9 & 1.31 & 0.34 & 0.087 \\
\hline SA & 23.71 & 52.0 & 24.29 & 6.8 & 8.62 & 2.38 & 0.205 & 25.5 & 1.22 & 0.72 & 0.04 \\
\hline GR & 39.37 & 30.45 & 30.18 & 7.4 & 0.94 & 3.64 & 0.346 & 40.8 & 1.97 & 0.44 & 0.045 \\
\hline GR & 27.23 & 44.25 & 28.52 & 7.2 & 2.16 & 4.4 & 0.428 & 40.6 & 2.14 & 0.56 & 0.053 \\
\hline GR & 46.0 & 25.22 & 28.78 & 6.0 & 0.03 & 3.36 & 0.329 & 19.6 & 1.98 & 0.36 & 0.044 \\
\hline
\end{tabular}

Sand, silt, and clay are expressed in percentages, active $\mathrm{CaCO}_{3} \mathrm{TOC}$ (total organic carbon), and $\mathrm{N}$ are in percentages, and exchangeable cations are expressed in $\mathrm{cmol} \mathrm{x} \mathrm{kg-1}^{-1}$.

percentage of total calcium carbonate. Organic carbon levels are moderate and the $\mathrm{C} / \mathrm{N}$ ratio is above 10 .

The chemical soil variables analysed with PCA were used to investigate the overall impact of the top soil horizon on the presence of $T$. aestivum fruiting bodies. The first three factors account for $78.02 \%$ of the variance contained in the original matrix (Fig. 1). PC1 accounts for $37.99 \%$ of the variance and focuses on the differences between soils with a higher amount of $\mathrm{Ca}, \mathrm{K}, \mathrm{N}, \mathrm{TOC}, \mathrm{CaCO}_{3}, \mathrm{pH}$, and silt (Table 2). The second factor PC2 represents $22.68 \%$ of the variance and indicates the differences between soils with a higher percentage of clay and sand as well as the amount of $\mathrm{Mg}$. The third factor, PC3, accounts for $17.35 \%$ of the variance and shows differences between soils with accounts of $\mathrm{Na}$ (Table 2).

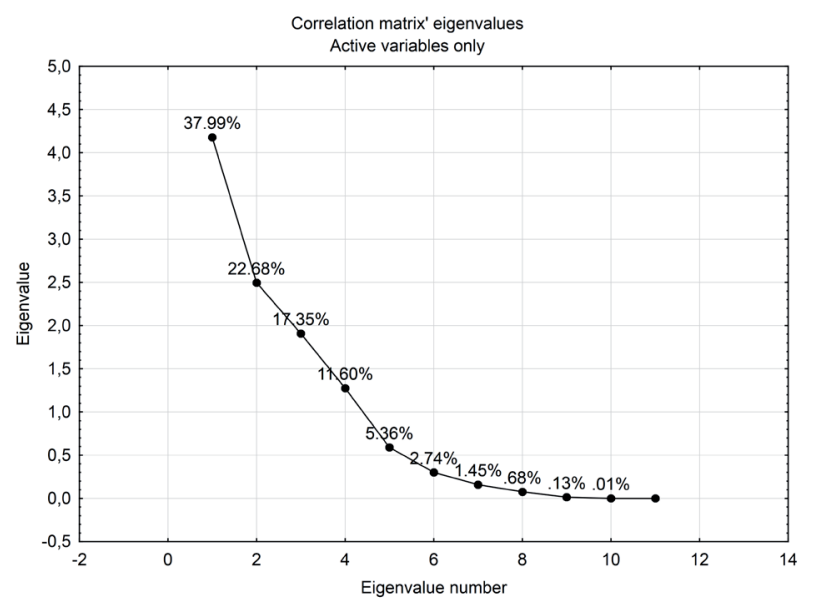

Fig. 1. Scree plot of principal component analysis (PCA).
Fig. 2 shows correlations between variables. Positively correlated are the variables whose vectors lay close to themselves, for example $\mathrm{K}$, silt, $\mathrm{CaCO}_{3}$, and $\mathrm{pH}$. These variables are negatively correlated with $\mathrm{Mg}$ and sand. Amounts of $\mathrm{Na}$ are negatively correlated with $\mathrm{Ca}$, TOC, and N. Most analysed soils were characterized by rather low concentrations of $\mathrm{CaCO}_{3}$ (Table 1, Fig. 3). The soils with a higher percentage of $\mathrm{CaCO}_{3}$ showed positive correlation with the number of fruiting bodies of T. aestivum (Fig. 3).

Table 2. Coefficients of soil variables according to PCA (factors loadings).

\begin{tabular}{|c|c|c|c|}
\hline Variables & $\begin{array}{c}\text { Factor 1 } \\
(\mathrm{PC} 1)\end{array}$ & $\begin{array}{c}\text { Factor 2 } \\
\text { (PC2) }\end{array}$ & $\begin{array}{c}\text { Factor 3 } \\
\text { (PC3) }\end{array}$ \\
\hline Sand & 0.489 & -0.798 & 0.269 \\
\hline Silt & -0.631 & 0.279 & 0.355 \\
\hline Clay & -0.046 & 0.677 & -0.588 \\
\hline $\mathrm{pH}$ & -0.773 & 0.012 & 0.043 \\
\hline $\mathrm{CaCO}_{3}$ & -0.635 & 0.129 & 0.566 \\
\hline $\mathrm{TOC}^{\mathrm{N}}$ & -0.828 & -0.403 & -0.306 \\
\hline $\mathrm{Ca}^{2+}$ & -0.735 & -0.588 & -0.238 \\
\hline $\mathrm{Mg}^{2+}$ & -0.825 & -0.177 & -0.427 \\
\hline $\mathrm{K}^{+}$ & -0.233 & 0.732 & -0.511 \\
\hline $\mathrm{Na}^{+}$ & 0.301 & 0.408 & -0.670 \\
\hline
\end{tabular}




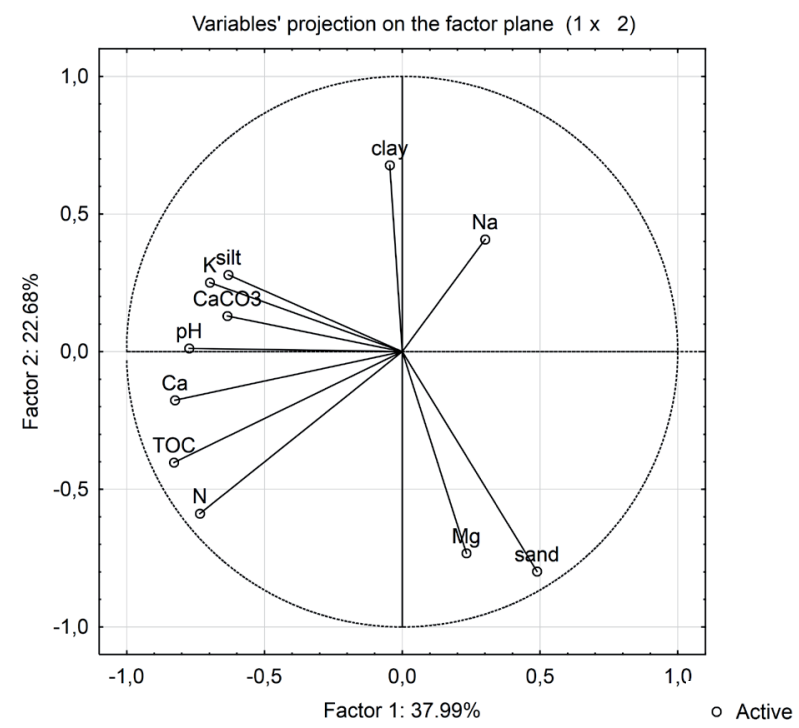

Fig. 2. Relationship between variables of soils typical of T. aestivum.

\section{Discussion}

Data on T. aestivum ecology are still rather sparse due to the fact that the species is less valued (economically and culinary) than, for example, T. melanosporum. Although T. aestivum is widely distributed throughout Europe [1, 17], researchers have given it less attention. Our data showed that the development of Burgundy truffle fruiting bodies is influenced by content of carbonates. Both forms of the carbonates, namely $\mathrm{CaCO}_{3}$ and exchangeable $\mathrm{Ca}^{2+}$, regulate $\mathrm{pH}$, the latter form being more relevant for truffle development (Fig. 2, Table 2). An increase of $\mathrm{CaCO}_{3}$ content positively affected a number of $T$. aestivum fruiting bodies (Fig. 3). This corresponds to the broad opinion that truffles in general, and Burgundy truffle in particular, require high calcium availability in the soils [18].

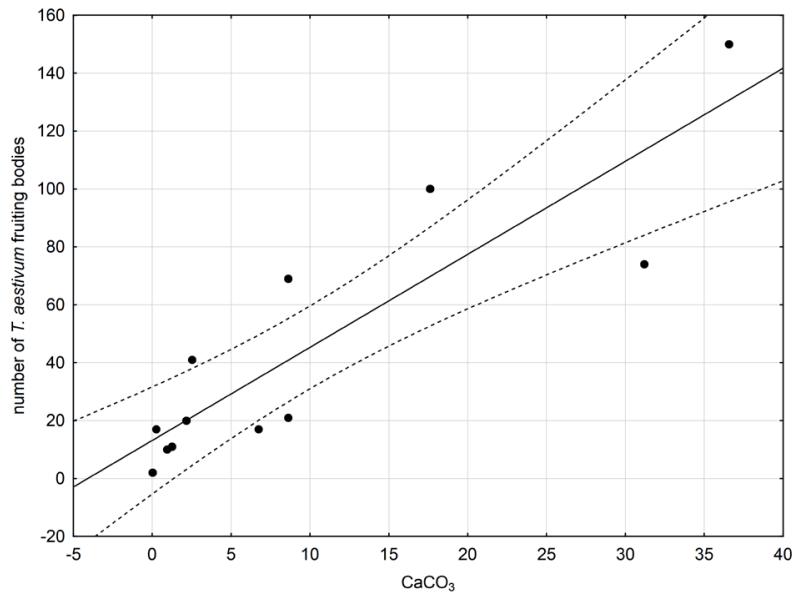

Fig. 3. Correlation between content of $\mathrm{CaCO}_{3}$ in soils and number of $T$. aestivum fruiting bodies $(\mathrm{r}=0.88, \mathrm{n}=12)$.
Moreover, Gryndler et al. [9] suggest that high bioavailability of calcium stimulates the development of truffle mycelium. The importance of carbonates for proper development of three truffle species T. melanosporum, T. aestivum, and T. mesentericum - has been highlighted by some authors [11, 19, 20]. The role of active carbonate in the formation of truffle fruiting bodies was observed clearly in the case of $T$. melanosporum [11]. In a review by Chevalier and Sourzat [20] dedicated to soil requirements of T. aestivum, the authors showed variability of calcium carbonate levels in truffle orchards in France, Italy, Hungary, and Sweden. For example, in France the level of limestone is highly variable and ranges from $0.4 \%$ to $52 \%$. In Italy, the level of calcium carbonate in T. aestivum soils is just as variable, although generally it is relatively low and ranges between $0.9 \%$ and $12 \%$. However, in the region of Parma, it can be as high as $52.9 \%$, with an average of $21.9 \%$. In Hungary most of the soils contain little $(5-8 \%)$ or only traces of lime $(0.1-5 \%)$, while in Sweden total limestone can be from just a trace to $10.5 \%$. Our data on this aspect (Table 2) seems to fit perfectly into these findings. The ranges of other nutrients $(\mathrm{C}, \mathrm{N}, \mathrm{Ca}$, and $\mathrm{K})$ that are very important for T. aestivum development were similar to those found at Swedish and French truffle orchards [20]. For our T. aestivum the $\mathrm{pH}$ is generally weakly alkaline or neutral, or possibly mildly acidic (6.0-7.6), and in this context resembling the soils in Hungary and Sweden [21, 22] more than the soils in France and Italy, where due to the constant presence of limestone from the surface down, the $\mathrm{pH}$ is always above 7 and ranges between 7.1 and 8 in the A1 horizon [20]. However, Thomas [23] found that the lowest optimal $\mathrm{pH}$ for mycorrhiza of T. aestivum development is 7.51 .

Analysing the structure of investigated soils, we found that sandy textures are less conducive to truffle development (Fig. 2). The result is in accordance with findings by Chevalier and Sourzat [20]. At T. aestivum sites in natural forests in Poland, the soil texture is highly variable, ranging from silty-clay to clayey-silt and more rarely silty, silty-sandy, or clayey. The analysed soils varied from "heavy" (up to $55.4 \%$ clay) to "light" (up to $46 \%$ sand). The great diversity in soil texture at T. aestivum sites is well documented in the literature [11, 19, 20, 24, 25]. The "light" soils are generally thought to be less favourable for truffle cultivation. However, even excessively sandy soils can support truffle development if they are sufficiently rich in calcium [20]. Thus, $T$. aestivum appears to have a wide tolerance for soil texture as it develops in sedimentary terrain of various geological ages, from Palaeozoic to Quaternary and recent alluvia. Moreover, T. aestivum fruit bodies are able to grow on alkaline volcanic substrates [26]. This diversity of substrates (and the fact that T. aestivum is less thermophilic than $T$. melanosporum) explains the broad geographic distribution of this species - from Morocco to Sweden and from Ireland to Azerbaijan [2]. In Poland, as well as in France and Italy [20], 
the soils where $T$. aestivum occurs are typically rendzinas on terrain derived from sedimentary rocks (marly limestone) from the Mesozoic (Cretaceous).

The ecological and pedo-climatic requirements of the Burgundy truffle allows the fungus to adaptat to different environments typical of the Mediterranean region and in northern and eastern Europe as well. The main challenge of research about $T$. aestivum soils is to estimate very precisely the optimal conditions favourable for fruiting bodies' growth. It is also important to characterize conditions that facilitate the colonization and persistence of T. aestivum mycorrhizas on root systems. This knowledge is a key factor for establishing best management practices in truffle orchards, such as irrigation, soil tillage, supplies of organic matter, and nutrients. Our results are a new input of knowledge in this aspect and are important for truffle growers, especially in new areas outside the Mediterranean region.

\section{Conclusions}

The data show that content of calcium is crucial for fructification of $T$. aestivum fruiting bodies together with the soil's $\mathrm{pH}$ level and the share of the silt fraction.

\section{Acknowledgements}

This work was supported by the State Forests National Forest Holding (grant No. OR.271.3.6.2015) and the Polish Ministry of Science and Higher Education (grant No. 240 318). The authors wish to express their appreciation to the reviewers for their comments and suggestions.

\section{Conflict of Interest}

The authors declare no conflict of interest.

\section{References}

1. PACIONI G., COMANDINI O. Tuber. In Ectomycorrhizal Fungi Key Genera in Profile, Cairney J. W. G., Chambers S. M., Eds., Springer Berlin Heidelberg, Germany, 163. 1999.

2. CHEVALIER G. The truffle of Europe (Tuber aestivum): geographic limits, ecology and possibility of cultivation. In Proceedings of the First Conference on the "European" Truffle, Greilhuber A., Hausknecht I., Urban A., Eds., Wien, Austria: Österreichische Mykologische Gesellschaft, 249, 2010.

3. GRANETTI B., DE ANGELIS A.M.G. Umbria, terra di tartufi. Regione Umbria Gruppo Micologico ternano: Terni, Italy, 2005.
4. PEGLER D.N., SPOONER B.M., YOUNG T.W.K. British truffles: a revision of British hypogeous fungi. Kew Royal Botanic Gardens: Richmond, UK, 1993.

5. ROSA-GRUSZECKA A., HILSZCZAŃSKA D., GIL W., KOSEL B. Truffle renaissance in Poland - history, present and prospects. Journal of Ethnobiology and Ethnomedicine, 13 (1), 36, 2017.

6. HILSZCZAŃSKA D., SIEROTA Z., PALENZONA M. New Tuber species found in Poland. Mycorrhiza, 18 (4), 223, 2008.

7. HILSZCZAŃSKA D., ROSA-GRUSZECKA A., SIKORA K., SZMIDLA H. First report of Tuber macrosporum occurrence in Poland. Scientific Research and Essays, 8 (23), 1096, 2013.

8. ROSA-GRUSZECKA A., HILSZCZAŃSKA D., SZMIDLA H. Environmental conditions that promote the occurrence of truffles (Tuber spp.) on historical sites in Poland. Forest Research Papers, 75 (1), 5, 2014.

9. GRYNDLER M., BESKID O., HUJSLOVÁ M., KONVALINKOVÁ T., BUKOVSKÁ P., ZEMKOVÁ L., HRŠELOVÁ H., JANSA J. Soil receptivity for ectomycorrhizal fungi: Tuber aestivum is specifically stimulated by calcium carbonate and certain organic compounds, but not mycorrhizospheric bacteria. Applied Soil Ecology, 117-118 (May), 38, 2017.

10. STOBBE U., EGLI S., TEGEL W., PETER M., SPROLL L., BÜNTGEN U. Potential and limitations of Burgundy truffle cultivation. Applied Microbiology and Biotechnology, 97 (12), 5215, 2013.

11. GARCÍA-MONTERO L.G., DÍAZ P., MARTÍNFERNÁNDEZ S., CASERMEIRO M. A. Soil factors that favour the production of Tuber melanosporum carpophores over other truffle species: a multivariate statistical approach. Acta Agriculturae Scandinavica, Section B Soil \& Plant Science, 58 (4), 322, 2008.

12. MOSER B., BÜNTGEN U., MOLINIER V., PETER M., SPROLL L., STOBBE U., TEGEL W., EGLI, S. Ecological indicators of Tuber aestivum habitats in temperate European beech forests. Fungal Ecology, 29, 59, 2017.

13. GRYNDLER M., ČERNÁ L., BUKOVSKÁ P., HRŠELOVÁ H., JANSA J. Tuber aestivum association with non-host roots. Mycorrhiza, 24 (8), 603, 2014.

14. HILSZCZAŃSKA D., ROSA-GRUSZECKA A., SZMIDLA, H. Characteristic of Tuber spp. localities in natural stands with emphasis on plant species composition. Acta Mycologica, 49 (2), 267, 2014.

15. TRACZYK T. Próba podsumowania badań nad ekologicznym zróżnicowaniem grądów w Polsce. Acta Societatis Botanicorum Poloniae, 31 (4), 621, 1962.

16. MOLINIER V., PETER M., STOBBE U., EGLI S. The Burgundy Truffle (Tuber aestivum syn. uncinatum): A Truffle Species with a Wide Habitat Range over Europe BT. In True Truffle (Tuber spp.) in the World: Soil Ecology, Systematics and Biochemistry. Zambonelli A., Iotti M., Murat C., Eds., Springer International Publishing, 33, 2016.

17. HILSZCZAŃSKA D., SIEBYŁA M., HORAK J., KRÓL M., PODSADNI P., STECKIEWICZ P., BAMBUROWICZ-KLIMKOWSKA M., SZUTOWSKI M.,TURŁO J. Comparison of Chemical Composition in Tuber aestivum Vittad. of Different Geographical Origin. Chemistry \& Biodiversity, 13 (12), 1617, 2016.

18. MONFORT-SALVADOR I., GARCÍA-MONTERO L., GRANDE M. Impact of calcium associated to calcareous 
amendments on ectomycorrhizae in forests: a review. Journal of soil science and plant nutrition, 15 (1), 217, 2015.

19. GARCÍA-MONTERO, L. G., VALVERDE-ASENJO, I., MORENO, D., DÍAZ, P., HERNANDO, I., MENTA, C., TARASCONI, K. Influence of Edaphic Factors on Edible Ectomycorrhizal Mushrooms: New Hypotheses on Soil Nutrition and C Sinks Associated to Ectomycorrhizae and Soil Fauna Using the Tuber Brûlé Model. In Edible Ectomycorrhizal Mushrooms: Current Knowledge and Future Prospects. Zambonelli A., Bonito G.M., Eds., Springer Berlin Heidelberg, Germany, 83, 2012.

20. CHEVALIER G., SOURZAT P. Soils and Techniques for Cultivating Tuber melanosporum and Tuber aestivum in Europe. In Edible Ectomycorrhizal Mushrooms: Current Knowledge and Future Prospects. Zambonelli A., Bonito G.M., Eds., Springer Berlin Heidelberg, Berlin, Heidelberg, Germany, 163, 2012.

21. WEDÉN C., PETTERSSON L., DANELL E. Truffle cultivation in Sweden: Results from Quercus robur and Corylus avellana field trials on the island of Gotland. Scandinavian Journal of Forest Research, 24 (1), 37, 2009.

22. GÓGÁN A.C., NAGY Z., DÉGI Z., BAGI I. Ecological characteristics of a Hungarian summer truffle (Tuber aestivum Vittad .) producing area. Acta Mycologica, 47 (2), 133, 2012.

23. THOMAS P.W. The role of $\mathrm{pH}$ in Tuber aestivum syn. uncinatum mycorrhiza development within commercial orchards. Acta Mycologica, 47 (2), 161, 2012.

24. PONCE A.R., ÁGREDA T., ÁGUEDA B., ALDEA J., MARTÍNEZ-PEÑA F., MODREGO M.P. Soil physical properties influence "black truffle" fructification in plantations. Mycorrhiza, 24 (S1), 55, 2014.

25. JAILLARD B., BARRY-ETIENNE D., COLINAS C., DE MIGUEL A. M., GENOLA L., LIBRE A., NEVUE P., OLIACH D., SAENZ W., SÁEZ M., SALDUCCI X., SOUCHE G., SOURZATE P., VILLENEUVE M. Alkalinity and structure of soils determine the truffle production in the Pyrenean Regions. Forest Systems, 23 (2), 364, 2014.

26. ROBIN C., GOUTAL-POUSSE N., LE TACON F. Soil Characteristics for Tuber aestivum (Syn. T. uncinatum). In True Truffle (Tuber spp.) in the World: Soil Ecology, Systematics and Biochemistry. Zambonelli A., Iotti M., Murat C., Eds., Springer International Publishing, 211, 2016. 